удК 658.336

\title{
ЛЮДИНООРІЄНТОВАНИЙ ЦІННІСНИЙ ПІДХІД ДО РОЗВИТКУ УПРАВЛІНСЬКОГО ПОТЕНЦІАЛУ ПІДПРИЕМСТВА
}

\author{
HUMAN VALUES-ORIENTED APPROACH \\ TO ENTERPRISE MANAGEMENT CAPACITY \\ DEVELOPMENT
}

\author{
Лактіонова Олександра Анатоліївна \\ доктор економічних наук, доцент, \\ Донецький національний університет імені Василя Стуса \\ ORCID: https://orcid.org/0000-0001-6472-6503 \\ Гуменюк Роман Петрович \\ аспірант, \\ Донецький національний університет імені Василя Стуса \\ ORCID: https://orcid.org/0000-0002-3253-327X \\ Laktionova Oleksandra, Humeniuk Roman \\ Vasyl' Stus Donetsk National University
}

\begin{abstract}
Стаття містить результати досліджень щодо формування людиноорієнтованого ціннісного підходу до розвитку управлінського потенціалу підприємства. Запропонована концепція дозволяє виявити основні ціннісні орієнтири як для підприємства, так і для кожного підрозділу та фрахівця. Такі принципи повинні бути єдині для всього персоналу підприємства та є основою для професійного та особистого розвитку персоналу управління. Складові управлінського потенціалу оцінюються на відповідність визначеним цінностям та стратегічним цілям підприємства. Різноманітні складові управлінського потенціалу з одного боку тісно пов'язані між собою (в першу чергу через фокусування на фрахівця з управління), а з іншого боку мають свої особливості як в плануванні, так і в реалізації. Визначення цінностей підприємства, їх відповідності стратегічним цілям дозволяє сорормувати єдину систему принципів діяльності та розвитку управлінського потенціалу. Такий підхід $\epsilon$ ефективним як для профресійного, так і для особистого зростання та реалізації потенціалу управлінського персоналу. Використання VRIO-аналізу, визначення таксономічних показників та методу ієрархахій дозволить сорормувати стратегії розвитку управлінського потенціалу, порторель проектів з подальшим визначенням їх фрінансового забезпечення.
\end{abstract}

Ключові слова: людиноорієнтований підхід до управління підприємством, управлінський потенціал, управлінський потенціал персоналу підприємства, стратегія розвитку управлінського потенціалу, фрінансове забезпечення, показники розвитку управлінського потенціалу підприємства, VRIO-аналіз.

Статья содержит результаты исследований по вопросам формирования человекоориентированного ценностного подхода к развитию управленческого потенциала предприятия. Предложенная концепция позволяет выявить основные ценностные ориентиры как для предприятия, так и для каждого подразделения и специалиста. Такие принципы должны быть едины для всего персонала предприятия и являются основой для профессионального и личного развития персонала управления. Составляющие управленческого потенциала оцениваются на соответствие определенным ценностям и стратегическим целям предприятия. Различные составляющие управленческого потенциала с одной стороны тесно связаны между собой (в первую очередь из-за фрокусировки на специалиста по управлению), а с другой стороны имеют свои особенности как в планировании, так и в реализации. Определение ценностей предприятия, их соответствия стратегическим целям позволяет ссрормировать единую систему принципов деятельности и развития управленческого потенциала. Такой подход является эфффективным как для профессионального, так и для личного роста и реализации потенциала управленческого персонала. Использование VRIO-анализа, определения таксономических показателей и метода иерархий позволит сорормировать стратегии развития управленческого потенциала, порторель проектов с последующим определением их фринансового обеспечения. Человеко-ориентированный подход к управлению предприятием; управленческий потенциал; управленческий потенциал персонала 
предприятия; стратегия развития управленческого потенциала; фринансовое обеспечение; показатели развития управленческого потенциала предприятия; VRIO-анализ.

Ключевые слова ориентированный на личность подход к управлению предприятием, управленческий потенциал, управленческий потенциал персонала предприятия, стратегия развития управленческого потенциала, финансовое обеспечение, показатели развития управленческого потенциала предприятия, VRIO-анализ.

The article contains the results of research on the formation of a new approach to capacity management, taking into account the values of the individual, enterprise, and its units. to the development of the managerial potential of the enterprise. The proposed concept allows identifying the main values for both the company and for each department and specialist. Such principles should be the same for all staff. They are the basis for the professional and personal development of management staff. Components of management capacity are assessed for compliance with certain values and strategic goals of the enterprise. The various components of managerial capacity are closely related on the one hand (primarily through the focus on the management specialist), and on the other hand, have their own characteristics in both planning and implementation. Defining the values of the enterprise, its compliance with strategic goals allows forming a unified system of principles of activity and development of managerial potential. This approach is effective for both professional and personal growth and realization of the potential of management staff. The use of VRIO-analysis, determination of taxonomic indicators, and the method of hierarchies will allow forming strategies for the development of management capacity, a portfolio of projects with the further determination of their financial support. Each component of management potential is focused on the development of staff, the individual, and its development, along with the introduction of innovation, corporate culture, information system, and more. Each component of management capacity has its priority for different stages of enterprise development and the peculiarities of the development of the industry, which belongs to the enterprise and can be assessed by quantitative and qualitative indicators. The development of each component of management capacity should have a positive impact on the development of the enterprise as a whole. The formed concept of the human-oriented value approach to the development of management capacity is the basis for the formation of a system of determinants for assessing the level of development of management capacity for individual components and integrated indicators. At the stage of evaluating the determinants of human-oriented value approach to the development of enterprise management potential and establishing causal links between components, it is necessary to form criteria for establishing causal links between components, as well as strategic goals of enterprise development as a result of its economic activity and development. enterprises as a socio-economic system. The proposed approach allows to form taxonomic indicators for each component of management capacity development and identify the most priority projects for its development. In terms of further research - testing of the proposed approach at the enterprises of Vinnytsia region.

Keywords a human-oriented approach to enterprise management, managerial potential, managerial potential of the company's staff, management capacity development strategy, financial support, indicators of development of the managerial potential of the enterprise, VRIO analysis.

Постановка проблеми. Розвиток управлінського потенціалу підприємства $€$ одним 3 напрямів забезпечення успішного фрункціонування системи управління, реалізація стратегічних та оперативних завдань на всіх рівнях діяльності підприємства. Збалансування цінностей розвитку підприємства, його підрозділів та особистих цінностей персоналу, орінансове забезпечення інвестицій на розвиток потенціалу управління $€$ одним 3 непростих завдань для керівництва підприємства. Це обумовлено фррагментарними зв'язками між сорормованою стратегією розвитку підприємства, його фрактичною господарською діяльністю, процесами управління, навчання персоналу, розвитку корпоративної культури тощо. Різноманітні складові управлінського потенціалу з одного боку тісно пов'язані між собою (в першу чергу через фоокусування на фрахівця з управління), а з іншого боку мають свої особливості як в плануванні, так і в реалізації. Визначення цінностей підприємства, їх відповідності стратегічним цілям дозволяє сорормувати єдину систему принципів діяльності та розвитку управлінського потенціалу. Такий підхід $є$ еорективним як для професійного, так і для особистого зростання та реалізації потенціалу управлінського персоналу.

Аналіз останніх досліджень і публікацій. Людино-орієнтований ціннісний підхід орормується на двох базових підходах - максимізація цінності для власників та максимізація багатофракторної цільової фрункції для всіх зацікавлених сторін. Однією з теорій, що дозволяють визначити детермінанти розвитку управлінського потенціалу та його фрінансового забезпечення на основі людиноорієнтованого ціннісного підходу $є$ концепція Value-Based Management (VBM) [1-4]. Автор концепції А. Раппопорт виділяє чотири основних елементи управління - оцінювання, як процес визначення цінності організації для власників, моніторинг показників, визначення механізмів для створення нових цінностей; 
стратегія як сукупність цільових заходів для підвищення цінності організації для її власників; фрінанси - як показник окупності інвестицій; корпоративне управління - як система балансу інтересів власників та менеджерів; стимулювання діяльності фрахівців та вищого рівня менеджменту. Якщо запропоновану концепцію використати для системи розвитку управлінського потенціалу, то сам управлінський потенціал вже є цінністю організації, яку необхідно розвивати, а для цього використовувати запропоновані напрями управління. Розвиток цієї концепції Г. Арнольдом [4] свідчить про те, що система матеріального стимулювання повинна базуватись на показниках прогнозування та оцінювання результатів діяльності, що не завжди має прямий зв'язок з показниками добробуту власників [4]. А. Мертенс та І. Смолін в своїх дослідженнях свідчать про те, що об'єктивних критеріїв оцінювання за визначеною концепцією не існує, тому що різні групи зацікавлених сторін мають різні критерії. Управлінський потенціал не можна оцінювати як показник вартості підприємства, але його рівень, як правило, зв'язаний з цією вартістю показниками прибутковості підприємства, тому можна відстежити закономірність - чим успішніше підприємство, тим більше інвестицій направлено на навчання персоналу, автоматизацію та інорорматизацію управлінських процесів; запровадження заходів корпоративної культури тощо [5-7].

Формулювання цілей статті (постановка завдання). Метою досліджень є фрормування людиноорієнтованого ціннісного підходу до розвитку управлінського потенціалу для визначення пріоритетності розвитку складових та орормування порторелю проектів розвитку.

Виклад основного матеріалу дослідження. Людиноорієнтований ціннісний підхід розвитку управлінського потенціалу базується на визначенні стратегічних цілей підприємства відповідно до таких основних фрункцій: профресійно компетентнісна; соціальна; інституційна; інноваційна; інфрормаційно-комунікаційна.

Профресійно-компетентнісна фрункція передбачає розвиток компетенцій управлінського персоналу; активне використання сучасних управлінських інноваційних методик; навчання; удосконалення особистих якостей управлінця як лідера, командного гравця тощо.

Соціальна фрункція передбачає врахування інтересів персоналу, створення сприятливого соціального клімату в колективі в цілому і кожному окремому підрозділі та команді. Інституційна фрункція передбачає фрормування ефективних організаційних структур та дотримання балансу між сталими структурами та динамічними проектними командами. Ефективне прийняття управлінських рішень та їх реалізація - один з показників розвитку управлінського потенціалу. Інноваційна фрункція передбачає запровадження інновацій на всіх рівнях управління, зокрема гнучких методологій управління, таймменеджменту, командного управління, самоменеджменту тощо. Інфрормаційно-комунікаційна фрункція передбачає використання екологічної інорормаційної системи, в якій здійснюється ефективна циркуляція інформації, її обробка та візуалізація для прийняття та реалізації управлінських рішень.

Таким чином, можна зробити висновок, що детермінанти розвитку управлінського потенціалу повинні базуватись на ключових детермінантах цінності відповідно до кожної зі складових. Такі детермінанти визначають пріоритетні сторони розвитку управлінського потенціалу, виявляють зв'язки між його складовими, впливають на фрормування та динаміку показників розвитку управлінського потенціалу відповідно до методів стратегічного управління підприємством. Для визначення основних детермінант розвитку управлінського потенціалу необхідно виконати етапи формування концепції оцінювання та прогнозування розвитку управлінського потенціалу за людиноорієнтованим ціннісним підходом; систематизувати детермінанти за складовими; сорормувати основні підходи до оцінювання показників розвитку управлінського потенціалу та взаємозв'язки між його складовими; визначити кількісні показники фрінансового забезпечення складових розвитку управлінського потенціалу. В таблиці 1 представлені основні складові розвитку управлінського потенціалу підприємства та відповідні детермінанти [8; 9].

Аналіз таблиці свідчить про такі загальні риси, притаманні всім складовим:

1. Кожна складова орієнтована на розвиток персоналу, окремої особистості та її розвитку.

2. Кожна складова має свою пріоритетність для різних етапів розвитку підприємств та особливостей розвитку галузі, якій належить підприємство і може бути оцінена за кількісними та якісними показниками.

3. Розвиток кожної складової повинен мати позитивний вплив на розвиток підприємства в цілому. 
Таблиця 1

Детермінанти управлінського потенціалу та особливостей його фінансового забезпечення відповідно до його складових

\begin{tabular}{|c|c|c|}
\hline $\begin{array}{c}\text { Складова розвитку } \\
\text { управлінського } \\
\text { потенціалу }\end{array}$ & Детермінанти & $\begin{array}{c}\text { Особливості } \\
\text { фрінансового забезпечення }\end{array}$ \\
\hline $\begin{array}{l}\text { Управлінський } \\
\text { потенціал } \\
\text { персоналу }\end{array}$ & $\begin{array}{l}\text { Кількісні показники розвитку персоналу } \\
\text { за освітнім рівнем, рівнем підвищення } \\
\text { кваліфікації, участі в успішних проек- } \\
\text { тах, досвіду роботи, результатів праці. } \\
\text { Якісні показники розвитку потенціалу } \\
\text { персоналу за компетенціями фрункцій } \\
\text { лідерства, комунікацій, організації, кре- } \\
\text { ативності тощо. } \\
\text { Кількісні та якісні показники результатів } \\
\text { запровадження проектів. Оцінювання } \\
\text { учасників команд за показниками про- } \\
\text { ектного менеджменту. } \\
\text { Рівень готовності персоналу щодо ро- } \\
\text { боти в середовищі інформаційної сис- } \\
\text { теми. }\end{array}$ & $\begin{array}{l}\text { Постійне фрінансове забезпе- } \\
\text { чення матеріального стимулю- } \\
\text { вання персоналу. } \\
\text { Періодичне фрінансове забез- } \\
\text { печення за результатами оці- } \\
\text { нювання персоналу } \\
\text { Фінансове забезпечення нав- } \\
\text { чання персоналу Фінансове } \\
\text { забезпечення окремих проек- } \\
\text { тів, а також заходів щодо фрор- } \\
\text { мування стратегії, проблемних } \\
\text { ситуацій тощо. }\end{array}$ \\
\hline $\begin{array}{l}\text { Потенціал } \\
\text { запровадження } \\
\text { інновацій в } \\
\text { управлінні }\end{array}$ & $\begin{array}{l}\text { Кількісні показники запровадження } \\
\text { інновацій в управлінські процеси; ре- } \\
\text { зультати запровадження інноваційних } \\
\text { проектів в систему управління. }\end{array}$ & $\begin{array}{l}\text { Фінансове забезпечення зап- } \\
\text { роваджених інновацій. Фінан- } \\
\text { сове забезпечення інновацій- } \\
\text { них проектів }\end{array}$ \\
\hline $\begin{array}{l}\text { Потенціал } \\
\text { запровадження } \\
\text { комплексної } \\
\text { інфорормаційної } \\
\text { системи }\end{array}$ & $\begin{array}{l}\text { Рівень охоплення управлінських про- } \\
\text { цесів; кількість сервісів для комунікацій } \\
\text { та візуалізації; показники рівня напо- } \\
\text { вненості та використання бази знань } \\
\text { для прийняття управлінських рішень } \\
\end{array}$ & $\begin{array}{l}\text { Фінансове забезпечення суп- } \\
\text { роводу роботи та оновлен- } \\
\text { ня комплексної інфрормаційної } \\
\text { системи підприємства, інтер- } \\
\text { нет та зв'язку. }\end{array}$ \\
\hline $\begin{array}{l}\text { Потенціал розвитку } \\
\text { корпоративної } \\
\text { культури та } \\
\text { навчання }\end{array}$ & $\begin{array}{l}\text { Кількість корпоративних заходів; показ- } \\
\text { ники розвитку корпоративного інфрор- } \\
\text { маційного порталу; показники соціаль- } \\
\text { ного захисту працівників; показники } \\
\text { результатів навчання }\end{array}$ & $\begin{array}{l}\text { Фінансове забезпечення кор- } \\
\text { поративних заходів, підтримки } \\
\text { інфрормаційного порталу, стра- } \\
\text { ховки, соціальні виплати), дис- } \\
\text { танційних курсів підвищення } \\
\text { кваліфікікації, бази знань, зов- } \\
\text { нішнього навчання персоналу. }\end{array}$ \\
\hline
\end{tabular}

Джерело: розроблено авторами за [9; 11]

Відмінності до оцінювання та прогнозування показників складових розвитку управлінського потенціалу підприємства:

1. Складова розвитку корпоративної культури та навчання персоналу оцінюється за системою опитувань та рівня лояльності та залучення персоналу до управління підприємством на всіх рівнях.

2. Складова розвитку управлінського персоналу $€$ найбільш комплексною і включає в себе прямі показники виконання управлінських процесів та непрямі показники впливу рівня розвитку управлінського персоналу на результати діяльності підприємства.

3. Інноваційна складова розвитку управлінського потенціалу оцінюється рівнем запровадження інновацій в систему управління підприємством та виробництво товарів та послуг.
4. Складова розвитку інформаційних технологій передбачає оцінювання рівня готовності персоналу до ефективної роботи в середовищі інформаційної системи та охоплення управлінських процесів, зокрема процедур та процесів прийняття управлінських рішень.

Розвиток управлінського потенціалу збільшує його рівень та цінність саме на основі методики VRIO-аналізу. Адаптована до оцінювання рівня управлінського потенціалу, така методика дозволяє оцінити за чотирма напрямами - цінність (відповідність стратегічним цілям підприємства; якщо цінність на даному етапі не визначається - то пріоритетність), унікальність (особливо це стосується авторських управлінських технологій, фрахівців високого рівня, унікальних властивостей корпоративної культури тощо); здатність до безперервної діяльності (особливо в кризові 
періоди); організація (як ми вже вказували вище - баланс між сталими інституціями та динамічними проектними командами; організація навчання; підтримки тощо).

В таблиці 2. представлено загальні підходи до показників кожної складової розвитку управлінського потенціалу відповідно напрямам аналізу.

Оцінювання детермінант здійснюється відповідно до результатів опитування персоналу та експертів за бальною системою та фрормування загального показника за кожною складовою та інтегрованого показника розвитку управлінського потенціалу підприємства.

Показники фрінансового забезпечення оцінюються як показники інноваційно-інвестиційних проектів запровадження змін в управлінні, удосконалення інформаційної системи; корпоративної системи підприємства, витрат на навчання персоналу, підтримки департаментів за визначеними напрямами, витрати на систему управління персоналом, стимулювання та мотивації персоналу за прямими показниками витрат та ефективності, а також за показниками економії ресурсів: часу, людських та матеріальних ресурсів.

Сорормована система моніторингу, оцінювання та прогнозування взаємопов'язаних фрінансових і нефінансових показників, об'єднаних у межах людиноорієнтованого ціннісного управління дозволяє оцінити стан управлінського потенціалу та виявити складові, які необхідно розвивати в першу чергу.

Для кожної складової необхідно виявити основні детермінанти за ідентифікуючою, деталізуючою, конкретизуючою та доповнюючою ознаками $з$ подальшим узагальненням за інтегрованим показником підприємства як соціально-економічної системи.

Визначені показники складових за детермінантами розвитку управлінського потенціалу можуть бути оцінені за інтегральним показником з врахуванням вагомості та можливостей реалізації на даний момент відповідно до стратегічних напрямів розвитку управлінського потенціалу підприємства та основою для фрормування гнучкої системи фрінансового забезпечення проектів розвитку управлінського потенціалу.

Висновки із цього дослідження і дальші перспективи в цьому напрямку. Сорормована концепція людиноорієнтованого ціннісного підходу до розвитку управлінського потенціалу $€$ основою для фрормування системи детермінант для оцінювання рівня розвитку управлінського потенціалу за окремими

Таблиця 2

Адаптований VRIO-аналіз управлінського потенціалу підприємства

\begin{tabular}{|c|c|c|c|c|c|}
\hline Складові & $\begin{array}{c}\text { «V» } \\
\text { цінність }\end{array}$ & $\begin{array}{l}\text { «R» } \\
\text { унікаль- } \\
\text { ність }\end{array}$ & $\begin{array}{c}\text { «l» } \\
\text { Здатність до } \\
\text { безперервної } \\
\text { діяльності }\end{array}$ & $\begin{array}{c}\text { «О» } \\
\text { Організація }\end{array}$ & $\begin{array}{c}\text { Кількісне } \\
\text { значення } \\
\text { таксоно- } \\
\text { мічного } \\
\text { показника }\end{array}$ \\
\hline $\begin{array}{l}\text { Управлінський } \\
\text { потенціал } \\
\text { персоналу }\end{array}$ & \multirow{4}{*}{$\begin{array}{l}\text { Визначається } \\
\text { рівень цінності } \\
\text { складової } \\
\text { за стадією } \\
\text { господарської } \\
\text { діяльності } \\
\text { підприємства; } \\
\text { коефіцієнт } \\
\text { значущості за } \\
\text { результатами } \\
\text { опитування } \\
\text { та даними } \\
\text { орінансової та } \\
\text { управлінської } \\
\text { звітності за } \\
\text { шкалою від } \\
1 \text { до } 10 \text { та } \\
\text { нормалізується } \\
\text { від } 0 \text { до } 1\end{array}$} & \multirow{4}{*}{$\begin{array}{l}\text { Врахо- } \\
\text { вується при } \\
\text { формуванні } \\
\text { питань } \\
\text { анкети }\end{array}$} & \multirow{4}{*}{$\begin{array}{l}\text { Визначається } \\
\text { за резуль- } \\
\text { татами фінан- } \\
\text { сової звітності, } \\
\text { якісна характе- } \\
\text { ристика (так, ні), } \\
\text { враховується } \\
\text { за шкалою } \\
\text { від } 1 \text { до } 10 \text { та } \\
\text { нормалізується } \\
\text { від } 0 \text { до } 1\end{array}$} & \multirow{4}{*}{$\begin{array}{l}\text { Визначається } \\
\text { за резуль- } \\
\text { татами } \\
\text { анкетного } \\
\text { опитування } \\
\text { за шкалою } \\
\text { від } 1 \text { до } 10 \\
\text { та нормалі- } \\
\text { зується } \\
\text { від } 0 \text { до } 1\end{array}$} & \multirow{4}{*}{$\begin{array}{l}\text { Визначається } \\
\text { за методикою } \\
\text { розрахунків } \\
\text { таксономіч- } \\
\text { ного аналізу }\end{array}$} \\
\hline $\begin{array}{l}\text { Потенціал } \\
\text { запро- } \\
\text { вадження } \\
\text { інновацій в } \\
\text { управлінні } \\
\end{array}$ & & & & & \\
\hline $\begin{array}{l}\text { Потенціал } \\
\text { запро- } \\
\text { вадження } \\
\text { комплексної } \\
\text { інорормаційної } \\
\text { системи }\end{array}$ & & & & & \\
\hline $\begin{array}{l}\text { Потенціал } \\
\text { розвитку } \\
\text { корпора- } \\
\text { тивної } \\
\text { культури та } \\
\text { навчання }\end{array}$ & & & & & \\
\hline
\end{tabular}


складовими та інтегрованим показником. На етапі оцінювання детермінант людиноорієнтованого ціннісного підходу до розвитку управлінського потенціалу підприємства та встановлення причинно-наслідкових зв'язків між складовими необхідно сорормувати критерії для встановлення причинно-наслідкових зв'язків між складовими, а також зі стратегічними цілями розвитку підприємства як результатами його господарської діяльності та розвитку підприємства як соціально-економічної системи. Запропонований підхід дозволяє сорормувати таксономічні показники за кожною складовою розвитку управлінського потенціалу та визначити найбільш пріоритетні проекти для його розвитку. В плані подальших досліджень - апробація запропонованого підходу на підприємствах Вінницької області.

\section{СПИСОК ВИКОРИСТАНИХ ДЖЕРЕЛ:}

1. Value based managemen. URL: https://www2. deloitte. com/lu/en/ pages/strategy-operations/solutions/valuebased-management.html (дата звернення: 12.01.2021).

2. Malmi T., Ikäheimo S. Value Based Management practices-some evidence from the field. Management Accounting Research. 2003. Issue 3. P. 235-254. URL: https://www.sciencedirect.com/science/article/pii/ S1044 500503000477 (дата звернення: 12.01.2021).

3. Rappaport A. Creating shareholder value : The new standard for business performance. New York: The FreePress, 1998. 205 p.

4. Arnold G. Tracing the development of value based management. Value based management: context and application / Glen Arnold (eds), Matt Davies (eds). New York : John Wiley \&Sons, 2000. 388 p.

5. Мертенс А. В. Стоимость компаний в теории и на практике. Финансовый директор. 2002. № 5. С. 82-86.

6. Смолін І. В. Стратегічне планування розвитку організації : монограсія. Київ : Київський національний торгово-економічний ун-т, 2004. 344 с.

7. Бойко М. Методологічні основи формування ціннісно орієнтованого управління підприємствами. Вісник KHTEY. 2009. № 5. C. 74-84.

8. Маречик В. Я., Невмержицька С. М. Розвиток управлінського потенціалу як запорука успішного функціонування підприємства. Вісник Хмельницького національного університету. 2013. № 3. Т. 2. С. 237-242.

9. Гуменюк Р. П. Фінансове забезпечення управлінського потенціалу підприємства. Ефрективна економіка. 2020. № 6. URL: http://www.economy.nayka.com.ua/?op=1\&z=8081 (дата звернення: 12.01.2021).

10. VRIO Analysis. Management Mania. URL: https://managementmania.com/en/vrio-analysis (date of the application : 24.01.2021).

11. Лактіонова О. А. Гнучкість фрінансової системи: методологія, оцінка та вектори забезпечення: монографрія. Вінниця : Донецький національний університет, 2016. 400 с.

\section{REFERENCES:}

1. Value based managemen. Available at: https://www2.deloitte.com/lu/en/pages/strategy-operations/solutions/ value-based-management.

2. Malmi T. Ikaheimo S. (2003) Value Based Management practices-some evidence from the field. Management Accounting Research, no. 3, pp. 235-254. Available at: https://www.sciencedirect.com/science/article/pii/ S1044500503000477.

3. Rappaport A. (1998) Creating shareholder value: The new standard for business performance. New York : The FreePress.

4. Arnold G. (2000) Tracing the development of value based management. In Glen Arnold (Eds), Matt Davies (Eds) Value based management: context and application. New York : John Wiley \&Sons.

5. Mertens, A. V. (2002). Stoimost kompanij v teorii i na praktike [The value of companies in theory and practice]. Finansovyj direktor - CFO, no. 5, pp. 82-86. (in Russian)

6. Smolin I.V. (2004) Strategichne planuvannya rozvitku organizaciyi: monografiya [Strategic planning of organization development: monograph]. Kiyi: Kiyivckij nacionalnij torgovo-ekonomichnij un-t. (in Ukrainian)

7. Bojko M. (2009) Metodologichni osnovy formuvannya cinnisno oriyentovanogo upravlinnya pidpryyemstvamy [Methodological bases of formation of value-oriented management of enterprises]. Visnyik KNTEU - Bulletin of KNTEU, no. 5, pp. 74-84. (in Ukrainian)

8. Marechyik V.Ya. Nevmerzhyiczka S.M. (2013) Rozvyitok upravlinskogo potencialu yak zaporuka uspishnogo funkcionuvannya pidpryyemstva [Development of managerial capacity as a guarantee of successful operation of the 
enterprise]. Visnik Hmelnickogo nacionalnogo universitetu - Bulletin of Khmelnytsky National University, no. 3(2), 237-242. (in Ukrainian)

9. Gumenyuk R.P. (2020) Finansove zabezpechennya upravlinskogo potencialu pidpriyemstva [Financial support of the management potential of the enterprise]. Efektivna ekonomika - Efficient economy, no. 6. Available at: http://www.economy.nayka.com.ua/?op=1\&z=8081. (in Ukrainian)

10. VRIO Analysis. Management Mania. Available at: https://managementmania.com/en/vrio-analysis.

11. Laktionova O.A. (2016) Gnuchkist finansovoyi sistemi: metodologiya, ocinka ta vektori zabezpechennya: monografiya [Flexibility of the financial system: methodology, evaluation and vectors: monograph]. Vinnicya: Doneckij nacionalnij universitet. (in Ukrainian) 